УДК 333.45.01

DOI: $10.15673 /$ fie.v12i4.1909

\author{
Поліщук А.C. \\ викладач \\ кафедра оборонного менеджменту \\ навчально-науковий центр оборонного менеджменту \\ Національний університет оборони України \\ Повітрофрлотський проспект, 30, м. Київ, Україна, 03186 \\ E-mail: Polishchuk.an.@ukr.net \\ ORCID ID: 0000-0003-0558-6728
}

\title{
НАПРЯМИ РЕАЛІЗАЦІЇ ІННОВАЦІЙНИХ ПРОЕКТІВ НА ПІДПРИЄМСТВАХ
}

Інноваційний розвиток підприємств оборонно-промислового комплексу є основою економічної міцності держави, її конкурентних переваг на світовому ринку, запорукою збереження ринкової частки та отримання прибутку. Розвиток інноваційних технологій в Україні відбувається під впливом політичних та соціально-економічних перетворень. У даному дослідженні окреслено головні особливості інноваційних проектів у оборонно-промисловому комплексі України, які можуть бути використані в подальшому розвитку теми наукового дослідження роботи. У межах даного дослідження, 3 метою визначення ролі інноваційних проектів на підприємствах ОПК, проаналізовано багато тлумачень терміну «інноваційний проект», запропонованих як вітчизняними, так і зарубіжними вченими. Однак більшість із проаналізованих визначень у повній мірі не відображає специфіку підприємств ОПК. У зв'язку з цим у даному дослідженні пропонується використовувати власне тлумачення розглянутого терміну.

Ключові слова: інновації, проект, оборонно-промисловий комплекс, підприємств, типізація.

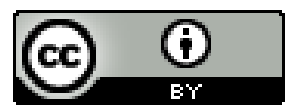

This work is licensed under a Creative Commons Attribution 4.0 International License http://creativecommons.org/licenses/by/4.0/
Постановка проблеми та її зв'язок з важливими науковими та практичними завданнями. Інноваційна діяльність є запорукою стабільного та ефективності функціонування суб’єктів господарювання в жорстких конкурентних умовах. Інноваційний розвиток підприємств оборонно-промислового комплексу (ОПК) є основою економічної міцності держави, іiі конкурентних переваг на світовому ринку, запорукою збереження ринкової частки та отримання прибутку. Розвиток інноваційних технологій в Україні відбувається під впливом політичних та соціальноекономічних перетворень. За словами академіка В. П. Горбуліна «попри всім відому істину, що впровадження інновацій при розробці та виробництві нового озброєння та військової техніки можливе лише за умови ефективної взаємодії науковців, замовників озброєння, розробників та виробників, в Україні $\epsilon$ багато прикладів того, що навіть наявний потенціал науки практично не використовується в оборонній сфері». Тому дослідження напрямів реалізації інноваційних проектів, їх типізація на підприємствах ОПК є актуальним.

Аналіз останніх публікацій по проблемі. Управління проектами як взаємозв'язок бізнеспроцесів із внутрішнім та зовнішнім середовищем розглядалися у наукових працях Й. Шумпетера, П. Друкера, Р. Ротвела, Е. Сіантова та ін. Питання формування складу інвестицій та інновацій знайшли відображення у дослідженнях Дж. Бейлі, I. Бланка, Т.
Майорова, Й. Стігліц, Р. Фатхутдінова. Науковці I. Дербо, І. Кінденгер, Ф. Найт, В. розвинули теорію ризик-менеджменту, у частині, принципів ідентифікації, оцінювання ризиків інвестування та управління ними.

Формулювання цілей дослідження. Метою даного дослідження $є$ визначення напрямів реалізації інноваційних проектів їх типізація на підприємствах ОПК.

Виклад основних результатів та їх обгрунтування. В межах даного дослідження, 3 метою визначення ролі інноваційних проектів на підприємствах ОПК, проаналізовано багато тлумачень даного терміну, запропонованих як вітчизняними, так і зарубіжними вченими. Зупинитися на тих з них, які відображають його зміст як категорії. Під проектом розуміють комплекс науково-дослідних, проектноконструкторських, соціально-економічних, організаційно-господарських та інших заходів, пов'язаних ресурсами, виконавцями та термінами, відповідно оформлених і направлених на зміну об'єкта управління, що забезпечує ефективність розв'язання основних завдань та досягнення відповідних цілей за певний період [1]. Кінцевими цілями проектів є створення та освоєння нової техніки, технології та матеріалів, що сприяє виходу вітчизняної продукції на світовий рівень. Наведемо ще кілька варіантів визначення поняття «проект», які зустрічаються в науковій літературі. Англійська асоціація проект-менеджерів надає 
таке визначення «проект - це окреме підприємство 3 конкретними цілями, які часто включають вимоги до часу, вартості та якості результатів, що досягаються» [2]. У академічному тлумачному визначено «проект це певне завдання з визначеними вихідними даними й встановленими результатами (цілями), що обумовлюють спосіб його вирішення [3].

Поняття «інноваційний проект» може розглядатись як «форма цільового управління інноваційною діяльністю - складна система взаємообумовлених і взаємопов'язаних за ресурсами, термінами і виконавцями етапів, спрямованих на досягнення конкретних цілей пріоритетних напрямів розвитку науки i техніки» [4]. В законі України «Про інноваційну діяльність» наводиться таке визначення «інноваційний проект - це комплект документів, що визначає процедуру і комплекс усіх необхідних заходів (зокрема інвестиційних) щодо створення і реалізації інноваційного продукту і (або) інноваційної продукції» [5].

У науковій літературі існують і непоширені точки зору. Так, В. Биковський вважає, що інноваційний проект - це процес цілеспрямованої зміни або створення нової технічної чи соціально-економічної системи [6]. В. Дорофєєв виділяє інноваційний проект «як різновид інвестиційного проекту, бізнеспроекту і представляє собою систему, яка містить безліч проектних рішень в науковій, технічній, виробничій, економічній (фінансової), управлінській, маркетинговій сфері» [7]. Однак більшість із проаналізованих визначень у повній мірі не відображає специфіку підприємств ОПК. У зв'язку з цим у даному дослідженні пропонується використовувати власне тлумачення розглянутого терміну. Інноваційний проект на підприємстві оборонно-промислового комплексу це комплекс упорядкованих заходів повного інноваційного циклу, які здійснюються в строго визначені терміни, що фінансуються державою, необхідних для досягнення цілей в передових областях науки та виробництва конкурентоспроможної продукції військового призначення, при цьому публічний доступ до змісту інноваційного проекту має гриф «таємно» або «цілком таємно». Підприємства ОПК є основою національної безпеки та гарантом незалежності держави. Від ефективного функціонування підприємств національної економіки країни, її науково-дослідних інституцій залежать управлінські рішення, щодо розробки та впровадження інноваційних систем озброєння та військової техніки. Для держави ефективне функціонування підприємств ОПК є стратегічно та життєво важливим завданням [8].

У «Дослідження і розробки НАН України 3 проблем підвищення обороноздатності і безпеки держави» зазначено, що зі 107 виконаних у рамках програми робіт 53 реалізовувалися в інтересах підприємств ДК «Укроборонпром», 18 - Міністерства оборони України та Генерального штабу Збройних Сил України, 12 - Державного космічного агентства України, 24 роботи були призначені для впровадження на інших підприємствах i в організаціях обороннопромислового комплексу, в тому числі у Громадській спілці «Ліга оборонних підприємств України». Нау- кові розробки за програмою були спрямовані на створення інноваційних та імпортозаміщуючих технологій, нових видів матеріалів, покриттів із заданими фізико-хімічними або медико-біологічними властивостями, інформаційних та програмних систем [9].

Стан ОПК на сучасному етапі характеризується такими особливостями:

По-перше, наявні два види виробництв - військове і цивільне; по-друге, підприємства ОПК реалізують широкий спектр інновацій (галузь виробляє значні обсяги інноваційної продукції); по-третє, переважають наукомісткі виробництва; по-четверте, підприємства ОПК представлені конструкторськими бюро, виробничими підприємствами i наукововиробничими об'єднаннями.

За оцінками експертів, у структуру ОПК входять 150 приватних та 167 державних підприємств, 3 них 130 підпорядковані ДК «Укроборонпром», Державному космічному агентству України - 12, Міністерству оборони - 8. За даними Держстату України, в 1994 р. в ОПК України працювало 1516 тис. осіб, у 2005 р. - 357 тис., у 2018 році - 137 тис. осіб. Різке зменшення кількості працівників ОПК створило проблему дефіциту висококваліфікованих кадрів [10]. Протягом 2014-2019 рр. ситуація в ОПК зрушилася у бік покращення. Активно розвивається приватний сектор ОПК: 69 \% обсягу державного оборонного замовлення у 2018 р. виконували приватні підприємства. [11]. У 2020 році на виконання державного оборонного замовлення передбачено фінансування у сумі 25,848 млрд. грн., що на 17 \% більше, ніж у 2019 р. Державним оборонним замовленням передбачається фінансування заходів з розвитку виробничих потужностей ОПК на загальну суму 2,53 млрд. грн. (9,8 \% від загального обсягу державного оборонного замовлення). 3 них 1,7 млрд. грн. спрямовуватимуться на виконання дослідних та дослідно-конструкторських робіт [11].

П’яте. Склад і кількість етапів інноваційного процесу на підприємствах ОПК залежать від типу підприємств та особливостей виробництва, реалізація інноваційних проектів здійснюються в строго визначені терміни, проекти мають високий ступінь надійності, висока якість та нерозривно пов'язані із безпечним життєзабезпеченням, відсутній або обмежений публічний доступ до змісту інноваційних проектів.

Слід констатувати, що існують специфічні риси, які притаманні даній галузі та впливають на процес освоєння нової продукції. Дані особливості полягають у взаємовідносинах зі споживачами: підприємства, що працюють в ОПК, часто мають монопольне положення у пропозиції готової продукції. Разом 3 тим на діяльність ОПК впливають особливості територіального розміщення підприємств (виробничих комплексів), які мають ресурсну орієнтацію у регіонах. Різні інноваційні проекти реалізують абсолютно відмінні інновації та оцінюються з позицій специфіки проекту, його важливості, тому дослідники виділяють різні класифікації інноваційних проектів, за своєю природою та змістом.

Крім того, у підприємств ОПК спостерігаєть- 
ся висока частка державного замовлення в портфелі замовлень (від 70 до 100\%). Це, в свою чергу, призводить до висування високих вимог щодо якості продукції, що виробляється. Особливості ОПК як сфери господарювання полягають також у високій наукоємності та технологічності процесів розробки, виробництва продукції, і як наслідок, висока матеріаломісткість і фондомісткість виробництва.

Розглядаючи специфічні риси галузей ОПК в частині реалізації проектів, можна констатувати, що в даній галузі практично повністю відсутні приватні інвестиції при фінансуванні інвестиційних та інноваційних проектів. Проекти фінансуються або з власних коштів підприємств-реалізаторів, або за кошти, що державних цільових програмам.
На даний момент в науковій літературі недостатньо уваги приділено типології інноваційних проектів. Дослідження цього напряму вказують на різновекторні ознаки в класифікації інноваційних проектів. Представлені класифікації є типовими та можуть бути застосовні для спеціалізованих інноваційних проектів, зокрема, в ОПК. При цьому загальними ознаками в більшості класифікацій є: термін реалізації проекту; масштаб; джерело фінансування; об'єкт здійснення інноваційної діяльності; обсяги залучених ресурсів; тип інновації; рівень науково-технічної значущості; рівень новизни; ступінь ризику проекту.

3 огляду на зазначені особливості підприємств ОПК, запропонована класифікація інноваційних проектів (див. табл. 1).

Таблиця 1

Типологія інноваційних проектів на підприємствах ОПК*

\begin{tabular}{|l|l|}
\hline \multicolumn{1}{|c|}{ Ознака } & \multicolumn{1}{|c|}{ Види проектів } \\
\hline За напрямами здійснення інноваційної діяльності & Воєнні; конверсійні; цивільні \\
\hline За об’єктом здійснення інноваційної діяльності & Продуктові; технологічні; управлінські; концептуальні \\
\hline $\begin{array}{l}\text { За результатами здійснення інноваційної } \\
\text { діяльності }\end{array}$ & Нововведення; інновації \\
\hline За змістом етапів процесу розробки & $\begin{array}{l}\text { Ті, що містять всі етапи досліджень } \\
\text { Ті що містять обмежений зміст етапів. }\end{array}$ \\
\hline $\begin{array}{l}\text { За напрямами дії на основні технології, продукти } \\
\text { та ринки. }\end{array}$ & Розширюючі, заміщуючі. \\
\hline За кількістю етапів. & Багатоетапні, малоетапні. \\
\hline За часом здійснення & довгострокові, середньострокові, короткострокові. \\
\hline За видами ризику, що здійснює вплив на проект & $\begin{array}{l}\text { Високоризиковані, низькоризиковані, з оптимальним } \\
\text { рівнем ризику }\end{array}$ \\
\hline За рівнем таємності & Таємні, цілком таємно, з обмеженим доступом \\
\hline За рівнем рішення & $\begin{array}{l}\text { національні, державні, регіональні, міжгалузеві, окре- } \\
\text { мого підприємства }\end{array}$ \\
\hline
\end{tabular}

*Розроблено автором

Надалі розглянемо особливості за етапами галузях ОПК (табл. 2). реалізації проекту освоєння нового продукту в

Таблиця 2

Особливості проектів освосння нових продуктів в галузях ОПК за етапами реалізації проекту*

\begin{tabular}{|l|l|}
\hline \multicolumn{1}{|c|}{ Етап реалізації проекту } & \multicolumn{1}{c|}{ Особливості } \\
\hline $\begin{array}{l}\text { Визначення ідеї нового продукту та її попередня } \\
\text { оцінка }\end{array}$ & $\begin{array}{l}\text { В галузях ОПК початковим етапом є не генерація но- } \\
\text { вих ідей, а отримання заявки від потенційного замов- } \\
\text { ника. При цьому, чим нижче ступінь кооперації підп- } \\
\text { риємства при виробництві головної продукції, тим } \\
\text { менший ступінь НдДКР необхідний при освоєнні його } \\
\text { випуску. }\end{array}$ \\
\hline $\begin{array}{l}\text { Дослідження споживчих властивостей нового } \\
\text { продукту і аналізу його перспективного ринку }\end{array}$ & $\begin{array}{l}\text { Визначення необхідних якостей нового продукту від- } \\
\text { бувається в тісній взаємодії із замовником, так як ви- } \\
\text { роблений продукт є унікальним. }\end{array}$ \\
\hline Організація дослідного виробництва & Роботи під контролем представників замовника \\
\hline Організація серійного виробництва & $\begin{array}{l}\text { Фінансування за рахунок власних коштів, залучених } \\
\text { коштів за цільовими програми }\end{array}$ \\
\hline Початок комплексної програми збуту & Наявність В2В, В2С маркетингу \\
\hline \multicolumn{2}{|c|}{ жозроблено автором }
\end{tabular}


Проект $з$ освоєння нового продукту в галузях ОПК може реалізовуватися в дев'ять основних етапів, що поєднуються із загальноприйнятими стадіями управління проектом. Впровадження інструментів проектного управління в практику діяльності вітчизняних підприємств ОПК дозволить підвищити інноваційний потенціал комплексу. Практика менеджменту стверджує, що впровадження методів та інструментів проектного управління дозволяє економити до 20 \% коштів і до $30 \%$ часу при реалізації проектів та програм. 3 огляду на специфіку оборонного комплексу, управління проектами являє собою реальну альтернативу існуючій практиці управління. Як переваги впровадження проектного управління інноваційною діяльністю підприємств ОПК слід зазначити наступні: зниження числа збоїв при реалізації проекту, скорочення часу виконання проектів, зменшення загальної вартості проекту, визначення та аналіз ефективності інвестицій в конкретний проект [4].

У свою чергу, процесне освоєння нового продукту не має жорсткої структури і регулюється внутрішніми стандартами та регламентами підприємства. У таких умовах терміни реалізації проекту, вартісні, трудові витрати на його реалізацію жорстко не контролюються, тому часто не зрозуміло, чи є новий продукт ефективним. Проектний підхід до освоєння нового продукту дозволяє зробити цей процес більш ефективнішим за часом, за рахунок структурування операцій на всіх рівнях та організації контролю витрат ресурсів на освоєння нового продукту.

Таким чином, основні особливості проектів розробки та освоєння випуску нових продуктів у галузях ОПК полягають у державному регулюванні ціноутворення, ступені унікальності розробок, контролі якості нових продуктів, що випускаються, з боку замовника на всіх етапах виробництва, в залучені джерела фінансування проектів.

Висновки та перспективи подальших досліджень. Узагальнюючи все вищевикладене, доцільно зробити наступний висновок. Інноваційний проект є одним із способів реалізації інновацій, що визначає спроможність економічної системи до розвитку за допомогою реалізації методики інноваційного проекту. На підприємствах ОПК реалізуються продуктові та технологічні інноваційні проекти, однак їм практично не властиві ринкові та маркетингові. Таким чином, запропонована типологія інноваційних проектів враховує специфіку діяльності підприємств ОПК. Розглядаючи різні підходи до класифікації інноваційних проектів, необхідно враховувати, що систематизація класифікаційних ознак має особливе значення. Кожна класифікація має здатність дати детальне уявлення щодо характеристики того чи іншого інноваційного проекту, що, в свою чергу, необхідно для здійснення адекватної підтримки з боку держави, реалізації інноваційних проектів на різних підприємствах.

\section{Лiтература}

1. Бібліотека економіста: [інтернет-портал]. Київ, 2017. URL: https://library.if.ua/book/66/4897.html (дата звернення 21.10.2020)

2. Офіційний веб-сайт Української асоціації управління проектами [Веб-сайт]. Одеса, 2020. URL: http://upma.kiev.ua/index.php?lang=ukrainian (дата звернення 25.10.2020)

3. Словник української мови Академічний тлумачний словник (1970-1980): [інтернет-портал]. Київ, 2015. URL: http://sum.in.ua/(дата звернення 25.10.2020)

4. Василевська А. Управління проєктами підприємства із використанням інформаційних технологій // Вісник КНТЕУ. 2018. № 1. С. 99-105.

5. Про інноваційну діяльність: Закон України за станом на 05.12.2012 / Верховна Рада Украӥни. URL: https://zakon.rada.gov.ua/laws/show/40-15\#Text (дата звернення: 25.10.2020).

6. Биковський В. В. Управление организацией. М.: Инфра-М, 2011. 822 с

7. Дорофеев В. Д. Инновационный менеджмент: учеб. пособие. Пенза: Изд-во Пенз. гос. ун-та. 2013. $189 \mathrm{c}$.

8. Стратегії розвитку оборонно-промислового комплексу України на період до 2028 року: [інтернетпортал]. Київ, 2017. URL: https://zakon.rada.gov.ua (дата звернення: 25.10.2020).

9. Дослідження і розробки НАН України з проблем підвищення обороноздатності і безпеки держави: [інтернет-портал] https://www.ukrmilitary.com/2020/03/nan.html

10. Державна служба статистики України: [Веб-сайт]. Київ, 2020. URL: http://www.ukrstat.gov.ua/ (дата звернення: 25.10.2020).

11. Бегма В. М. Концептуальні засади стратегій інвестиційно-інноваційного розвитку обороннопромислових комплексів держав. Досвід для України. Київ: НІСД, 2019. 264 с. 


\author{
Полищук А.C. \\ преподаватель \\ кафедра оборонного менеджмента \\ учебно-научный центр оборонного менеджмента \\ Национальный университет обороны Украины \\ Воздухофрлотский проспект, 30, г. Киев, Украина, 03186 \\ E-mail: Polishchuk.an.@ukr.net \\ ORCID ID: 0000-0003-0558-6728
}

\title{
НАПРАВЛЕНИЯ РЕАЛИЗАЦИИ ИННОВАЦИОННЫХ ПРОЕКТОВ НА ПРЕДПРИЯТИЯХ
}

\begin{abstract}
Инновационное развитие предприятий оборонно-промышленного комплекса - основа экономической мощи государства, его конкурентных преимуществ на мировом рынке, залог сохранения доли рынка и прибыли. На развитие инновационных технологий в Украине влияют политические и социально-экономические преобразования. В данном исследовании выделены основные отличительные черты инновационных проектов в оборонной промышленности Украины. Данные особенности могут быть использованы при дальнейшем изучении данной темы научного исследования. В рамках исследования с целью определения роли инновационных проектов в оборонной промышленности изучено много трактовок термина «инновационный проект» как отечественными, так и зарубежными учеными. Однако большинство проанализированных определений не полностью отражают специфику оборонных предприятий. Поэтому в данном исследовании предлагается использовать собственное толкование термина. Процесс разработки нового продукта не имеет жесткой структуры и регулируется внутренними стандартами и регламентами предприятия. В таких условиях сроки реализации проекта, стоимость, трудозатраты на его реализацию строго не контролируются, поэтому часто неясно, эфрфективен ли новый продукт.

Инновационный проект - это один из способов реализации инноваций, который определяет способность экономической системы развиваться за счет реализации методологии инновационного проекта. На предприятиях оборонной промышленности реализуются продуктовые и технологические инновационные проекты, но они практически не характеризуются рыночные и маркетинговые. Таким образом, предлагаемая типология инновационных проектов учитывает специфику деятельности оборонных предприятий. Рассматривая различные подходы к классификации инновационных проектов, следует иметь в виду, что систематизация классификационных признаков имеет особое значение. Каждая классификация имеет возможность дать подробное представление об особенностях того или иного инновационного проекта, что, в свою очередь, необходимо для реализации адекватной поддержки со стороны государства, реализации инновационных проектов на различных предприятиях.
\end{abstract}

Ключевые слова: инновации, проект, оборонно-промышленный комплекс, предприятия, типизация.

\author{
Polishchuk A. \\ Teacher \\ Department of Defense Management \\ Training and Research Center of Defense Management \\ The National Defense University of Ukraine \\ Povitroflotskyi Avenue, 30, Kyiv, Ukraine, 03186 \\ E-mail: Polishchuk.an.@ukr.net \\ ORCID ID: 0000-0003-0558-6728
}

\section{DIRECTIONS OF REALIZATION OF INNOVATIVE PROJECTS AT THE ENTERPRISES}

Innovative development of enterprises of the defense-industrial complex is the basis of economic strength of the state, its competitive advantages in the world market, the key to maintaining market share and profit. The development of innovative technologies in Ukraine is influenced by political and socioeconomic transformations. This study outlines the main features of innovative projects in the defense industry of Ukraine, which can be used in the further development of the topic of scientific research. In the frame- 
work of this study, in order to determine the role of innovative projects in the defense industry, many interpretations of the term "innovative project "have been proposed by both domestic and foreign scientists. However, most of the analyzed definitions do not fully reflect the specifics of defense enterprises. Therefore, in this study, it is proposed to use your own interpretation of the term. The process of development of a new product does not have a rigid structure and is governed by internal standards and regulations of the enterprise. In such conditions, the project implementation dates, cost, labor costs for its implementation are not strictly controlled, so it is often unclear whether the new product is effective.

An innovation project is one of the ways to implement innovations, which determines the ability of the economic system to develop through the implementation of the methodology of the innovation project. Product and technological innovation projects are implemented at the enterprises of the defense industry, but they are practically not characterized by market and marketing. Thus, the proposed typology of innovative projects takes into account the specifics of the activities of defense enterprises. Considering the different approaches to the classification of innovative projects, it should be borne in mind that the systematization of classification features is of particular importance. Each classification has the ability to give a detailed idea of the characteristics of a particular innovation project, which, in turn, is necessary for the implementation of adequate support from the state, the implementation of innovative projects in various enterprises.

Key words: innovations, project, defense-industrial complex, enterprises, typification.

\section{References}

1. Biblioteka ekonomista. (2017). Retrieved October 21, 2020, from https://library.if.ua/book/66/4897.html

2. Ofitsiinyi veb-sait Ukrainskoi asotsiatsii upravlinnia proektamy. (2020). Retrieved October 25, 2020, from http://upma.kiev.ua/index.php?lang=ukrainian

3. Slovnyk ukrainskoi movy. Akademichnyi tlumachnyi slovnyk (1970-1980). (2015). Retrieved October 25, 2020, from http://sum.in.ua/

4. Vasylevska, A. (2018). Upravlinnia proiektamy pidpryiemstva iz vykorystanniam informatsiinykh tekhnolohii. Visnyk KNTEU, (1), 99-105.

5. Pro innovatsiinu diialnist: Zakon Ukrainy za stanom na 05.12.2012. Verkhovna Rada Ukrainy. (2012). Retrieved October 25, 2020, from https://zakon.rada.gov.ua/laws/show/40-15\#Text.

6. Bikovskiy, V. (2011). Upravlenie organizatsiey. Moscow: Infra-M.

7. Dorofeev, V. (2013). Innovatsionnyiy menedzhment. Penza: Izd-vo Penz. gos. un-ta.

8. Stratehii rozvytku oboronno-promyslovoho kompleksu Ukrainy na period do 2028 roku. Verkhovna Rada Ukrainy. (2017). Retrieved October 25, 2020, from https://zakon.rada.gov.ua

9. Doslidzhennia i rozrobky NAN Ukrainy z problem pidvyshchennia oboronozdatnosti i bezpeky derzhavy. (2020). Retrieved October 25, 2020, from https://www.ukrmilitary.com/2020/03/nan.html

10. Derzhavna sluzhba statystyky Ukrainy. (2020). Retrieved October 25, 2020, from http://www.ukrstat.gov.ua/

11. Behma, V. (2019). Kontseptualni zasady stratehii investytsiino-innovatsiinoho rozvytku oboronnopromyslovykh kompleksiv derzhav. Dosvid dlia Ukrainy. Kyiv: NISD.

Received 30 October 2020

Approved 14 November 2020

Available in Internet 29.12.2020

Цитування згідно ДСТУ 8302:2015

Поліщук А.С. Напрями реалізації інноваційних проектів на підприємствах // Економіка харчової промисловості. 2020. Т.12, вип. 4. С. 35-40. doi: 10.15673/fie.v12i4.1909

Cite as APA style citation

Polishchuk, A. (2020). Directions of realization of innovative projects at the enterprises. Food Industry Economics, 12(4), 35-40. doi: 10.15673/fie.v12i4.1909 